\title{
SPECIFIC OF LOCAL GOVERNMENT PROCUREMENT MANAGEMENT IN GEORGIA
}

\author{
Nana Shonia ${ }^{1}$, \\ Zurab Mushkudiani², \\ Sulkhan Makhatadze ${ }^{3 \mathrm{i}}$ \\ ${ }^{1}$ Akaki Tsereteli State University, \\ Kutaisi, Georgia \\ ${ }^{2}$ Batumi Navigation Teaching University, \\ International Teaching University \\ of Management and Communication - Alterbridge, \\ Batumi/Tbilisi, Georgia \\ ${ }^{3} \mathrm{PhD}$ Student in Business Administration, \\ Georgian Technical University, \\ Tbilisi, Georgia
}

\begin{abstract}
:
Procurement at the local self-government level in Georgia is carried out in accordance with the rules established by the Law of Georgia on State Procurement. In this case, the difference between local and state procurement is not observed at the concept level, the specifics of the municipalities are not considered anywhere. The main objectives of the Law on Public Procurement are to rationalize the funds allocated for procurement, as well as to ensure a fair and non-discriminatory approach to procurement during procurement. However, violations of the principle of justice still occur at the municipal level. Due to the fact that procurement procedures take quite a long time and also, our research has revealed a number of shortcomings related to administration, hindering the effective functioning of municipalities.
\end{abstract}

JEL: H11; H70

Keywords: state procurement, management, municipal. government

\section{Introduction}

Local government procurement management in Georgia is known as "municipal procurement". It is one of the fundamental mechanisms for the provision of municipal services and the management process. Much of the management process, as well as most of the municipal services, is provided through local procurement.

i Correspondence: email sulkhanmakhatadze82@gmail.com 
Local procurement means the purchase by the municipality of any goods and services at its own expense, using electronic or other means. We describe these powers of the municipality in Article 19 (c) of the Local Government Code. The mayor of the municipality develops a procurement plan, approves it, and sends it to the Assembly not later than February.

Procurement at the local government level in Georgia is carried out under the Law of Georgia „On Public Procurement ${ }^{\prime \prime i i}$. The difference between local and state procurement at the conceptual level is not observed, and the specifics of municipalities are not taken into account anywhere (Gaprindashvil G. 2015) The primary objectives of the Public Procurement Law are both rational spending on procurement and ensuring a fair and non-discriminatory approach to the parties to procurement. However, violations of the principle of fairness still occur at the municipal level. Because the procurement procedures take quite a long time, the effective functioning of municipalities is difficult.

\section{Statement of the Problem}

It should also be noted that the procurement rules established by law apply to all types of local procurement, with the exception of:

- Water supply;

- Public procurement of part-time services provided for in the article of the budget classification "Goods and services";

- Public procurement for the lease of the appropriate meeting space;

- Public procurement related to the distribution of social advertising through the media (including websites and social networks);

- State purchases of postal and courier services from Georgian Post LLC;

- Public procurement of services of a legal entity of public law - National Bureau of Forensic Science by Levan Samkharauli.

According to the Law on Public Procurement, the application of procurement rules is mandatory when purchasing any goods, services, and construction works. This should be carried out at the expense of the budget of the self-governing unit, budgetary organizations, or an enterprise, the shares or shares of which are more than $50 \%$ owned by the municipality (Kikvadze O 2016). The latter is a rarity in Georgia's reality.

For those business entities, more than $50 \%$ of whose shares belong to the local government, a clarifying entry is made in the law: the rules established by the Procurement Law are mandatory for these entities to purchase. In this case, there is an exception when the specified enterprise, due to the specifics of its activities, is guided by special rules established by the Government of Georgia for the procurement of the same goods or services. This rule cannot be valid for more than two years. This special rule should be developed by the Ministry of Economy and Sustainable Development of Georgia $^{\text {iii }}$ or the Ministry of Regional Development and Infrastructure of Georgia on the basis of proposals from the relevant enterprises and local self-government bodies. 
According to the definition of the Law of Georgia "On Public Procurement" and other legal acts, there are four types of public procurement in Georgia:

1) Simplified purchasing;

2) Simplified electronic tender;

3) Electronic tender and competition.

A simplified procurement process is used for public procurement of uniform procurement objects for an amount of up to GEL 5,000. However, there are other causes as well, namely:

1. When the supply of goods, the performance of work, or the provision of services is the exclusive right of only one person and there is no suitable alternative to the object of the procurement. The following cases do not apply to exclusive rights:

- The estimated cost of purchased goods or services exceeds GEL 2,000,000, and the cost of work is GEL 4,000,000. In addition, outside the country, within reasonable territorial limits, there is another person who can deliver the same goods, perform work or provide services;

- The estimated cost of purchased goods or services does not exceed 2,000,000 lari and work - 4,000,000 lari. There is another person in the country who can deliver the same goods, perform work or provide services;

2. When there is an urgent need, the number of purchased goods and the amount of work or services should not exceed the time required to solve urgent problems;

3. When the Procuring Entity is forced to subcontract the purchase of a new product or service because it was already defective. However, the cost should not exceed the cost of the first purchase;

4. When it is necessary to hold an event of state and public importance in a limited period. However, this must be determined by the relevant legal act of the Government of Georgia or self-governing units;

5. If necessary, replace one or more vehicles, computers, and electronic equipment with new ones.

6. When the Government of Georgia needs to purchase vehicle maintenance services or spare parts and lubricants necessary for the provision of these services.

Besides the above, goods and services worth 200,000 GEL or more can be purchased through a simplified procurement procedure so that they can be seamlessly carried out within the limited time frames planned by the government or municipalities.

As it known, a simplified electronic tender is a method for state purchases of homogeneous objects in the amount of up to 200,000 GEL. And an electronic tender is a method of state procurement of homogeneous objects in the amount of 200,000 GEL or more. In both cases, the procedures are determined in accordance with the procedures for simplified electronic tendering.

The difference between funds to buy is determined by differences between product groups and money thresholds. The public procurement system currently uses the classifier adopted by international organizations to identify procurement objects. The Common Procurement Vocabulary (CPV) of the European Union Directive EC N213 / 2008, which establishes a unified system of objects of public procurement and aims to 
standardize the guidelines used by procuring entities in describing the object of procurement.

The difference between simplified electronic trading and electronic trading, with the exception of monetary thresholds, is the timing of their implementation. The minimum period required for a simplified electronic competition is 3 days from the date of the announcement in the electronic system and 20 days for the electronic one. As for the tender, this procurement method can only be used for the procurement of engineering and design services. In this case, the buyer can make a decision based on other factors and price cannot be the deciding factor in determining the winning supplier.

During the study, we focused on the rights and obligations of the procuring entity, during which it was found that Article 7 of the Public Procurement Law authorizes the procuring entity:

- choose a supplier and conclude an agreement with him;

- disqualify candidates; in all three types of tenders, discontinue the procurement procedure at any time before the conclusion of the contract. However, it is necessary to confirm the reason for this;

- control the fulfillment of the terms of the contract by the supplier;

- suspend or terminate the contract if the qualification data provided by the supplier turns out to be false.

The procuring entity is required to:

- to carry out purchases rationally and taking into account the interests of the selfgoverning unit, but within the limits of the appropriations allocated to it;

- submit to the Agency reports on the purchases carried out;

- reimburse suppliers for the cost of goods, works, and services.

Procurement planning is of particular importance for efficient procurement management by municipalities. Procurement planning is the most important moment for the smooth functioning of self-government bodies. Correct planning leads to rational spending on procurement and is one of the main conditions for the transparency of the process. Procurement planning is based on the strategy and development priorities document of the municipality, which defines the activities and programs to be implemented during the year. Article 9 of the Law of Georgia "On Procurement" states that the buying entity must conduct procurement under a predetermined and approved annual plan. The form of the plan and the procedure for its preparation is determined by the order of the Chairman of the State Procurement Agency dated February 10, 2011, No. 2, which is called the "Procurement Rules of the Reporting Organization". The purpose of this is to ensure coordination and monitoring of all activities related to public procurement. This rule applies to all three procurement procedures. Based on the above, the municipality needs to purposefully develop a development strategy and prioritize by month and year, so as not to impede various activities because of procurement delays.

It is also rarely possible to involve field specialists and scientists in the development of a strategic development plan, which we consider necessary because it is the researchers and specialists in this field that can play a special role in the municipality's development. According to the Procurement Law, the Agency must notify the Buyer in 
advance about multi-year purchases. This should be reflected annually in the procurement plan for the relevant budget year. A multi-year procurement is not considered being a process in which they carried the procurement out only at the expense of the appropriations foreseen in the current year's budget, and it makes the delivery in the following year. When planning a purchase, it should not be artificially divided. According to article 3 (1) (c) of the Public Procurement Law, artificial unbundling of procurement is an action aimed at artificially reducing the number of homogeneous objects purchased by an organization from one source of funding during one budget year. The law also prohibits artificial segregation of procurement funds in order to avoid monetary constraints.

Legal framework for the management of municipal procurement. According to the Law on Public Procurement, an electronic tender must be conducted by a tender commission of at least 3 people. Members of the commission are appointed by the Mayor or his deputies, heads of structural divisions of the Board / City Hall. If necessary, other employees of the Management Board or the City Hall.

There are a lot of cases when a member of the City Council is included in this commission, which, in our opinion, is unjustified. Sakrebulo (Management Board) is a body that must control the activities of managers, including procurement. Thus, the inclusion of a member of Sakrebulo in the commission creates a conflict of interest. However, this is not limited by the law.

In addition to the staff of the Board / City Hall, experts in the relevant field may be invited to the Commission as consultants, who will have an advisory vote. In the event of a simplified electronic competition or an electronic competition, the competition committee makes decisions by a majority of votes of the list participants. If any member of the tender commission does not agree with the decision of the commission, he has the right to submit his opinion in writing. This conclusion must be attached to the decision of the tender commission. With an even distribution of votes, the vote of the chairman of the tender commission will be decisive. In addition to the Law on Public Procurement, the legal basis for procurement is created by by-laws of the State Procurement Agency, which define detailed rules, procurement procedures, and procurement forms. These are the orders of the Chairman of the State Procurement Agency, in particular:

- Order of September 20, 2010, No. 7 "On approval of the Rules for identifying and establishing the unity of procurement objects." The purpose of this rule is to identify, classify and determine the uniformity of procurement items. When determining uniformity in all cases of procurement, the classification adopted by international organizations should be taken into account;

- Order of November 30, 2015, No. 11 "On the regulations of the Commission for Resolution of Procurement Disputes under the State Procurement Agency". This rule applies to both simplified electronic bidding and disputes arising from public procurement through electronic bidding. The purpose of resolving such disputes is their prompt and fair resolution in accordance with the principle of equality of the parties; 
- Order No. 2 dated February 10, 2011 “On Approval of the Procuring Entity Reporting Rules". The purpose of this regulation is to coordinate and monitor public procurement procedures and activities. The order obliges the procuring entity to report in accordance with the document. This rule applies to all three forms of procurement;

- Order No. 9 dated April 7, 2011 “On Approval of the Rules for Conducting Simplified - Electronic Auction and Electronic Auction" explains how an interested party should purchase various goods or services. The order details simplified electronic tender procedures, procurement procedures, regulation, coordination and monitoring of activities;

- Order dated June 23, 2011, No. 15 “On the size of the tender application and tender documentation, as well as on the approval of the Rules for payment for the publication of tender documentation", establishes the amount of payment for the publication of tender documentation and the form of payment. Based on this document, the commission must be transferred to the deposit account of the Treasury Single Account;

- Order No. 24 of December 29, 2011 "On Approval of the Rules for Conducting TwoStage Simplified Electronic Auction and Two-Stage Electronic Auction" defines the legal framework, rules, and conditions for conducting two-stage simplified electronic tenders and an electronic tender. The tender includes two stages: in the first stage, the compliance of the technical documentation of the supplier with the tender requirements and the technical requirements established by the tender documentation is determined. They then evaluated the quality of the procurement object. The second phase includes additional rounds of e-commerce;

1. Order of February 27, 2015, No. 1 "On Approval of the Regulation of the Council for Resolution of Public Procurement Disputes" determines the rules and legal framework for the activities of the Council for Resolution of Disputes on Public Procurements in the Public Procurement Agency;

2. Order No. 7 dated May 22, 2015 “On Approval of the Rules and Conditions for Public Procurement of Design Services on a Competitive Basis" defines the rules and conditions for holding a tender for public procurement of design services, regulation, approval, and monitoring of the public procurement procedure by tender;

3. Order of May 21, 2015, No. 5 "On registration of a user in the unified electronic system of public procurement and approval of the Rules for the use of the unified electronic system of public procurement" defines the details of registration of procurement participants in the unified electronic system of public procurement; as well as issues related to the registration of their authorized representatives, changing the data of a registered user, deactivating a registered user and using the same public procurement system;

4. Order No. 13 of August 17, 2015 “On Approval of the Rules for Conducting Simplified Procurement and Approval of the Rules for Conducting Simplified Procurements" determines the grounds and criteria for making a decision on 
conducting public procurement in the manner of simplified procurement. In addition, it provides stakeholders with detailed information on how to reach an agreement with the Procurement Agency;

5. Order No. 27 of December 25, 2015 "On Approval of the Methodology for Identifying Artificial Division of Public Procurements" defines the methodology, rules, and conditions for identifying artificial division of public procurement by procuring organizations.

\section{Conclusion}

Thus, in Georgia, public procurement is carried out based on the aforementioned documents. However, without an electronic system, this process would be practically impossible. The transition to an electronic system has simplified the implementation of procurement for both self-governing purchasing organizations and suppliers. Even if there are at least 2 suppliers, the ultimate price in e-commerce is much lower than the estimated purchase price; as a result, public finances saved by procuring entities increase. In addition, the system is quite effective to save time and human resources for procuring organizations and combating corruption. With such a system, it practically excluded the possibility of a biased assessment by the members of the tender commission of the procuring entity. However, it should also be noted that using only the price criterion is risky, in particular, there is a risk of quality deterioration.

The lower activity of suppliers is a problem in the regions. Any tender is considered effective if there is a competitive environment, i.e. if at least two bidders take part in the tender. The situation in distant municipalities is disappointing. There are cases when no one takes part in the tender, and its announcement entails certain expenses of the self-governing entity. Another obligation of the buying entity creates another obligation - to ensure that the text materials, technical specifications, plans, drawings, sketches used in describing the technical and quality indicators of the procurement object comply with the standards recognized in Georgia and international practice.

Despite being introduced into legislation, municipalities still do not have access to these standards. Thus, it is not uncommon for an electronic tender to be announced and the technical part of the tender documentation lacks specificity, does not contain detailed instructions or standards that the service provider must be obliged to comply with. As a result, the services provided may be of poor quality and the municipality will have no legal leverage to require the service provider to remedy the problem in any way.

\section{Conflict of Interest Statement}

The authors declare no conflicts of interests.

\section{About the Authors}

Nana Shonia, is PhD holder in Economics, Professor of Finances from Akaki Tsereteli State University She has a wide experience in the lecturing position of over 15 years in a number of universities in Georgia. She has rose through the ranks to a senior lecturer 
position and has served as the dean of a faculty of Business, Law and Social Science. Her main area of interest is Finances, Banking, Insurance and Management. She permanently participates in local and international conferences.

Zurab Mushkudiani, Professor at International Teaching University of Management and Communication Alterbridge and Batumi Navigation Teaching University. He is a leading researcher and educator. He received his PhD from Akaki Tsereteli State University in 2015 and has worked on plenty of local and global educational scientific projects. Also, he worked in Kutaisi City Hall as a PR senior specialist and maintained relationship with public. He actively participates in local and international conferences. His research interests are Management, Finance and Education

Sulkhan Makhatadze, PhD student, from Georgian Technical University, Research interests: Municipal Finances and Economics. He has been taking participation in different conferences and trainings.

\section{References}

Gaprindashvili G. 2015 State Procurement Policy and its Impact on the Development of Entrepreneurship, Tbilisi

Kikvadze O. 2016 Improving Public Procurement in Public Finance Administration, Tbilisi.

Organic Law of Georgia 2014 - Code of Local Self-Government - Tbilisi, https://matsne.gov.ge/ka/document/view/2244429?publication=55 Accessed 14 April 2015

Law of Georgia on State Procurement, 2005 Tbilisi, https://matsne.gov.ge/ka/document/view/31252?publication=79 Accessed 2019

State Procurement Agency - http://www.procurement.gov.ge/ 
Authors will retain copyright to their published articles agreeing that a Creative Commons Attribution 4.0 International License (CC BY 4.0) terms will be applied to their work. Under the terms of this license, no permission is required from the author(s) or publisher for members of the community to copy, distribute, transmit or adapt the article content, providing a proper, prominent and unambiguous attribution to the authors in a manner that makes clear that the materials are being reused under permission of a Creative Commons License. Views, opinions and conclusions expressed in this research article are views, opinions and conclusions of the author(s). Open Access Publishing Group and European Journal of Economic and Financial Research shall not be responsible or answerable for any loss, damage or liability caused in relation to/arising out of conflict of interests, copyright violations and inappropriate or inaccurate use of any kind content related or integrated on the research work. All the published works are meeting the Open Access Publishing requirements and can be freely accessed, shared, modified, distributed and used in educational, commercial and non-commercial purposes under a Creative Commons Attribution 4.0 International License (CC BY 4.0). 